\title{
Improving the activities of learning and writing text description of students through contextual teaching and learning approach
}

\author{
Aisyah Nurlela ${ }^{1}$, Dessy Wardiah ${ }^{2}$, Yessi Fitriani $^{2}$ \\ ${ }^{1}$ Sekolah Menengah Pertama Negeri 13 OKU, Indonesia \\ ${ }^{2}$ Universitas PDRI Palembang, Indonesia
}

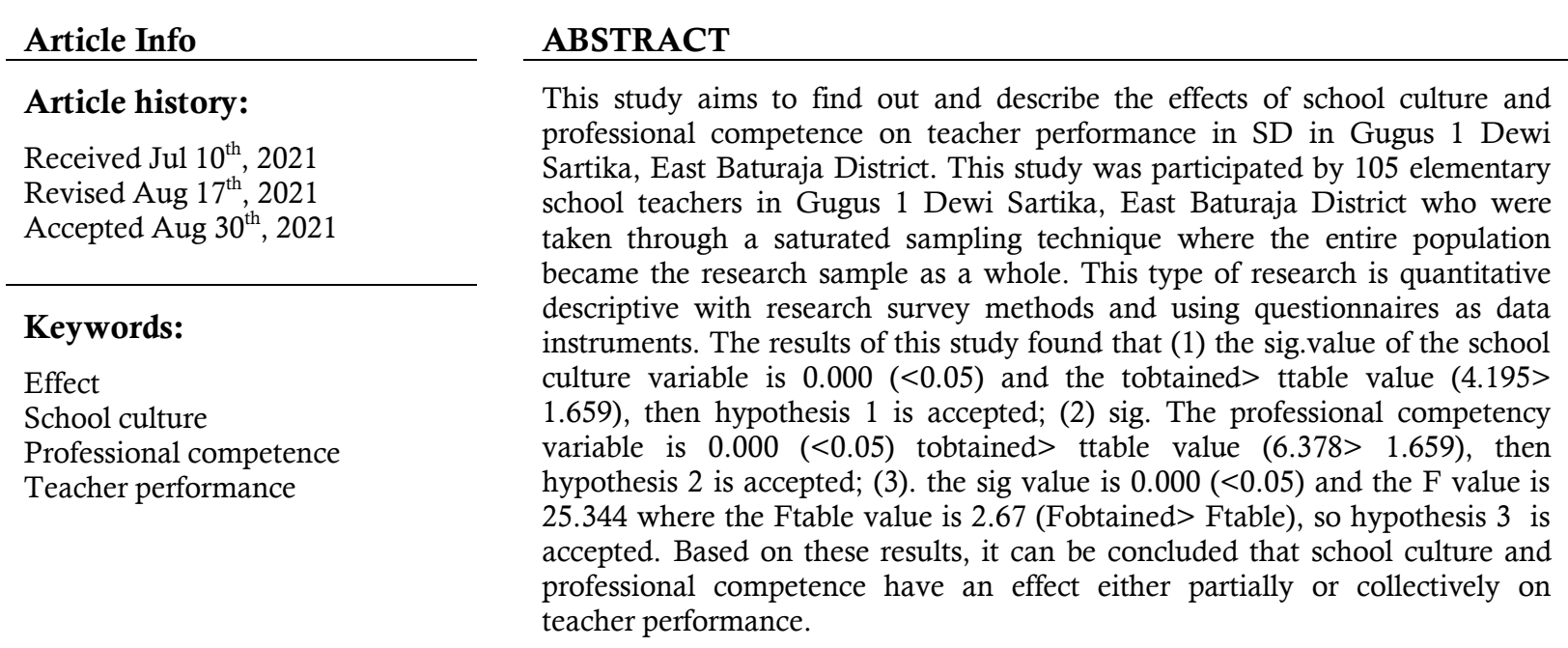

(C) 2021 The Authors. Published by IICET.

This is an open access article under the CC BY-NC-SA license

(https://creativecommons.org/licenses/by-nc-sa/4.0

\section{Corresponding Author:}

Nurlela, A.,

Sekolah Menengah Pertama Negeri 13 OKU, Indonesia

Email: aisyahnurlela65@gmail.com

\section{Introduction}

Writing as a language skill requires someone's expertise in using written language for communication purposes. Therefore, writing skills must involve a variety of skills, namely: (1) skills to express ideas or ideas, (2) skills to organize these ideas or ideas, (3) skills to apply grammatical and syntactic patterns, and (4) skills to choose structure and vocabulary [1].

In essence, the main function of language is as a means of communication. Therefore, learning Indonesian language and literature is directed so that students are skilled at communicating, both oral and written. Language learning in addition to improving language skills, is also to improve thinking skills, express ideas, feelings, opinions, consent, desires, convey information about an event and the ability to broaden horizons [2].

Learning Indonesian Language and Literature must be directed at the essence of Indonesian Language and Literature as a means of communication. As it is known that now language learning is changing, from an emphasis on learning the form aspects to learning which emphasizes the aspects of function. Generally, the information obtained from reading can have an effect on increasing knowledge and skills. Writing as a language skill is recognized by the public [3]. 
With regard to writing, one of them is writing descriptive text. Writing descriptive text is a writing competency that already exists and starts at the elementary school level. Students can express their feelings, ideas, and ideas to others through writing a description essay. The ability to write descriptive text is not automatically mastered by students, but must go through a lot of practice and regularly, so that students will find it easier to express themselves in writing activities. In this connection, the ability to write descriptive texts must be improved since childhood or starting from elementary school education.

One form of writing skill is writing a description essay. [4] argues that a description is an explanation or depiction in words of an object, place, atmosphere or event. The purpose of this description is as if the reader "sees" what he sees, can "hear" what he hears, can "smell" the thing he smells, can "taste" something he eats, can "feel" what he feels, so that the reader have the same conclusion as the author. Writing activity is one of the most recent manifestations of language skills and abilities mastered in language learning after listening, reading and speaking [4]. In the same book, it is also explained that when compared to other language skills, the ability to write is more difficult for language learners to master because writing skills require mastery of various other aspects outside of language, in order to produce coherent and coherent paragraphs or discourse.

With regard to good writing, it must have the following characteristics: (1) easy; (2) simple; (3) there is a means of delivery; and (4) right (Dalman, 2014: 83). Easy means that the writing is easy for the reader to understand and every reader likes the essay because it can be understood without any effort. Simple means that the sentences and words used in the essay are not exaggerated. Instantly means that the essay is not convoluted in expressing the subject matter. It means that the essay can really reflect the writer's thoughts so that it can be accepted by the reader.

Today's modern life, it is clear that writing skills are needed. It would not be too much to say that writing skills are a characteristic of an educated person or an educated nation. In this regard, Morsey is quoted by [5] explaining that writing is used to report / notify, influence, and such purposes and objectives can only be achieved properly by people who can compose their thoughts and express them clearly. This clarity depends on thought, organization, use of words, and sentence structure.

Based on the description stated above, what can be understood is that in other language skills, writing skills require a number of potential supporters. To achieve this, it takes seriousness, willpower, even through serious study. Thus, it is fair to say that improving writing skills will encourage students to be more active, creative and practice proficiency. To harmonize the Indonesian language learning process regarding writing descriptive text, it is necessary to have a learning approach so that the learning process can run effectively and efficiently. One approach that is considered good in learning to write descriptive essays is through the Contextual Teaching and Learning approach [6].

[7] there are several advantages in learning through the Contextual Teaching and Learning approach , namely: (1) learning is more meaningful, meaning that students carry out activities related to existing material so that students can understand them by themselves; (2) learning is more productive and able to foster concept reinforcement in students because learning through contextual demands students; (3) finding themselves not memorizing: (4) fostering the courage of students to express opinions about the material being studied; (5) fostering curiosity about the material being studied by asking the teacher: (6) fostering the ability to cooperate with other friends to solve existing problems; and (7) students can make their own conclusions from learning activities. The Contextual Teaching and Learning approach is teaching that allows students to strengthen, expand, and apply their academic knowledge and skills in various school and outside school settings to solve all problems in the real world [7].

Based on the results of preliminary observations, that $\mathrm{p}$ roses learning in SMPN 13 OKU in the school year $2020 / 2021$ held at 07.00 am up to $12.00 \mathrm{pm}$, which consists of ten study groups (class groups) which consists of classes VII- 1 to VII-10. The learning process of writing descriptive text, especially in class VII-1 SMP Negeri 13 OKU with a total of 32 students consisting of 15 male students and 17 female students is given only once a month, because the Indonesian language learning process refers to to the syllabus and Learning Implementation Plan (RPP), while other subject matter must also be provided. This resulted in the students' ability to write descriptive essays less than optimal. The learning process of writing descriptive text is only based on lectures and assignments, so that students who take part in the learning process become less active, less creative. It is proven that the ability to write descriptive text of students, who have achieved their learning completeness is as many as 11 students (34.4\%) with an average score of 72 and a KKM score of 70, while those who have not achieved completeness in writing descriptive text are as many as 21 students (65,6\%) with the achievement of an average score of 63 with a KKM score of 70 . This researcher examines that there are several factors that cause students' ability to write essays of descriptions not achieving mastery in learning, namely as follows. 
1. Students are less interested in writing material descriptions, because they are always given material in the same pattern and method (not varied);

2. Students are given more assignments, because other materials must also be provided to maximize the learning process.

3. Lessons given to students in writing descriptive essays are given using conventional;

4. Students are less active in participating in learning to write descriptive essays.

Based on the description of several factors that cause student learning outcomes to not achieve completeness in learning that have been stated above, researchers feel the need to apply an approach to learning that is creative and fun, namely through the Contextual Teaching and Learning approach, in order to obtain the results of an increase in learning activities and abilities. writing descriptive text for grade VII students at SMP Negeri 13 OKU.

The reason the researchers conducted research in class VII SMP Negeri 13 OKU was because the students assisted by the researchers themselves in carrying out the learning process, especially learning Indonesian. This is where the researchers realized themselves in the first semester of the school year $2020 / 2021$ is the target student researchers themselves, also in SMP 13 OKU no other researchers who conducted the study with the same title.

In connection with the above background, there are several reasons for the researcher to study writing descriptive texts for seventh grade students at SMP Negeri 13 OKU, namely: (1) the scores obtained by the students have not achieved the expected results; (2) the learning process is delivered using lectures and assignments; 3 ) no other researcher has conducted a similar study.

Based on the background description that the scores achieved by students have not reached the specified $\mathrm{KKM}$ and researchers want to find out more about the Indonesian language learning process related to writing descriptive texts with the title, " Increasing Learning Activities and Writing Descriptive Texts for Class VII Students at SMP Negeri 13 OKU through Approach to Contextual Teaching and Learning . ".

\section{Method}

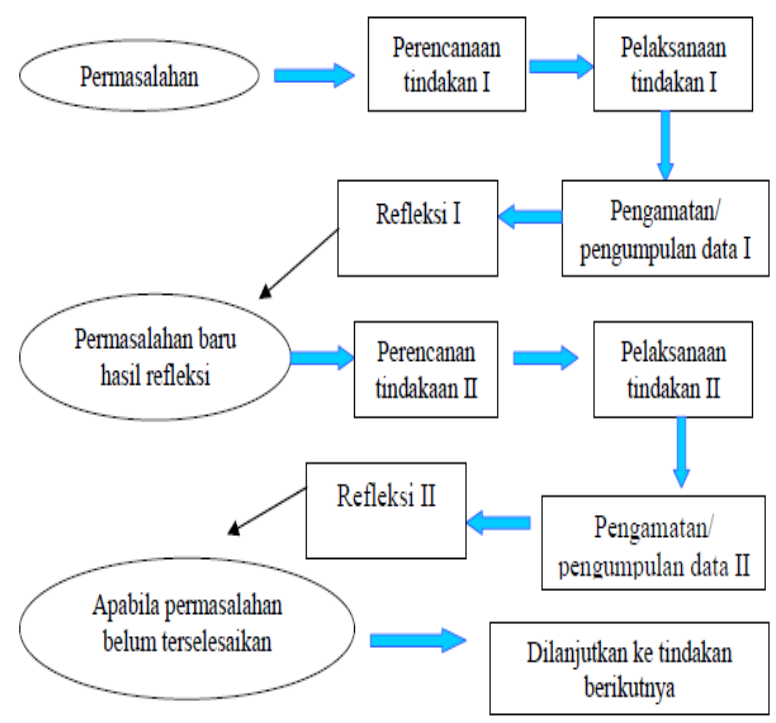

Figure 1<Research Flow Action (Supardi, 2012 : 105) $>$

According to Lewis [8], the procedure each cycle consists of four phases: planning ( planning ), (2) the action ( action ), (3) observation ( observasing ), (4), reflection ( reflecting). The flow of the research procedure can be described by the researcher as shown in the following figure 


\section{Results and Discussions}

Based on the research findings, it can be explained as follows.

\section{Discussion of Research Results on Cycle Action}

Based on the results of research findings on the action of increasing learning activities and writing descriptive texts of seventh grade students at SMP Negeri 13 OKU through the contextual teaching and learning approach in cycle 1 , the result was 2165 with an average of 67.66 . Students who reach KKM $\geq 70$ are 18 students or the average percentage of completeness achievement is $56.25 \%$.

\section{Discussion of Research Results on Cycle Action}

Based on the results of research findings on the action of increasing learning activities and writing descriptive texts of seventh grade students at SMP Negeri 13 OKU through the contextual teaching and learning approach in cycle 2, the result was 2229 or an average of 69.66 . Students who reach $K K M \geq 70$ are 26 students or the average percentage of completeness achievement is $81.25 \%$.

\section{Discussion of Research Results on Cycle Action}

Based on the results of research findings on the action of increasing learning activities and writing descriptive texts of seventh grade students at SMP Negeri 13 OKU through the contextual teaching and learning approach in cycle 3 , the result was 2313 with an average of 72.28 . Students who reach KKM $\geq 70$ are 30 students or the average percentage of completeness achievement is $93.75 \%$.

Several relevant research studies can be used as a reference in this research, such as research conducted [9] which examined, "Learning to Write Descriptions Using the Field Trip Method ." The results of his research state that through the Field Trip method, learning to write student descriptions is much better when compared to using conventional methods. This research can be said to have similarities and differences with current research, namely both researching writing descriptions. Furthermore, the difference is using the learning approach used.

[10] with the title, "Increasing the Ability to Write Student Descriptions by Using a Roll Playing Cooperative Learning Model in Class V SD Negeri 2 Empat Lawang. This study concludes that there is an increase in the ability to write essay descriptions of students after using the roll playing cooperative learning model in grade V SD Negeri 2 Empat Lawang. Students really like this learning model by being invited to role play, and other students see, listen and are asked to make essays and are described in writing what they see from the movements, speech and roles performed by their friends. This research can be said to have similarities and differences with current research, namely both researching writing descriptions. Furthermore, the difference is using the learning approach used.

[11] Entitled Efforts to Improve Descriptive Writing Skills through a Contextual Approach in Class IV Students of SDN Karanggedang 03 Sidareja Cilacap, 2009/2010 Academic Year. The results of his research state that through a contextual approach can improve the skills of writing descriptions in grade IV SDN Karanggedang 03 Sidareja Cilacap in the 2009/2010 academic year. This research can be said to have similarities and differences with current research, namely researching writing descriptions and using a contextual approach. Furthermore, the difference is the subject that is used as research.

Faridah's research (2015) examined, "Efforts to Improve the Ability to Write Descriptions of Class VIA Students at SD Negeri 3 Rambutan Rambutan Banyuasin through a contextual approach." The results of the research stated that the analysis of the descriptive writing test data for the fifth grade students of SD Negeri 3 Rambutan Banyuasin through a contextual approach in cycle 1 obtained an average value of 62.93. Students who reach $\mathrm{KKM} \geq 70$ are 6 students or the average percentage of completeness achievement is $24 \%$. Then in cycle 2, the results of the student scores have increased the average achievement of student learning outcomes by 68.99 . Students who reach $\mathrm{KKM}>70$ are 16 students or the average percentage of completeness achievement is $64 \%$. This shows that there is a fairly positive increase, even though the expected student learning outcomes have not achieved the specified results. Furthermore, in cycle 3 , it is known that the average score of student achievement is 81.28 . Students who reach $\mathrm{KKM} \geq 70$ are 23 students or the average percentage of completeness achievement is $92 \%$. This shows that there is a positive and very good increase. Based on the average learning outcomes of each cycle, it can be concluded that the contextual approach can improve the ability to write descriptions of the VIA class students at SD Negeri 3 Rambutan Banyuasin. This 
research can be said to have similarities and differences with current research, which is both researching writing descriptions by using a contextual approach. Furthermore, the difference lies in the subject that is used as research.

Aji's research (2013) entitled, "Efforts to Improve Descriptive Writing Skills by Using Image Media for Class IV Students of SD Singosaren Banguntapan Bantul, Yogyakarta." The results of his research explain that the results of observations in learning, the teacher has used image media and guided students in writing descriptive essays. The teacher also motivates students, so that they are more enthusiastic about learning. The results showed that using image media could improve students' description writing skills. The improvement of descriptive writing skills in the first cycle was 5.49, which in the initial condition the mean value was 65.06 , increasing to 70.55 . The improvement in writing descriptive writing skills in the second cycle was 9.81 , which in the initial condition the mean value of 65.06 increased to 74.87 . This research can be said to have similarities and differences with current research, namely both researching writing descriptions. Furthermore, the difference is using the learning approach used.

Putra's research (2018) with the title of learning to write descriptive texts in class VIII students of SMP Negeri 7 Bandar Lampung. The results of this study on the implementation of learning there are two activities, namely, teacher activities and student activities. The activities carried out by the teacher include three stages of activities, namely preliminary activities, core activities, and closing activities. In this activity, student activities occur which include (1) observing activities, (2) questioning activities, (3) trying activities, (4) reasoning activities, (5) communicating activities. The assessment carried out by the teacher includes attitude competency assessment using direct observation techniques, knowledge competency assessment using written test techniques in the form of description questions, and skills competency assessment using practical test techniques in the form of writing descriptive text essays. This research can be said to have similarities and differences with current research, namely both researching writing descriptions. Furthermore, the difference is the subject and place of research.

\section{Conclusions}

Based on the results of the study, it can be concluded that there is an increase in learning activities and writing descriptive text of VII grade students at SMP Negeri 13 OKU through the contextual teaching and learning approach from action cycle 1 to action cycle 2. Some of the findings of action research, factors that influence the unsuccessful action of the students has not been able to convey ideas in writing. After reflecting on the action cycle 2 and focusing more on the contextual teaching and learning approach, the results achieved in cycle 3 were even better than the previous cycle. Students who achieved completeness in learning activities and writing descriptive texts of seventh grade students at SMP Negeri 13 OKU through the contextual teaching and learning approach experienced a significant increase, so that by achieving KKM in action cycle 3, researchers did not continue the research.

\section{References}

Akhadiah, Sabarti dkk. 2017. Pembinaan Kemampuan Menulis Bahasa Indonesia. Jakarta: Erlangga.

Didi. Wijayanto. 2018. Dasar-Dasar Keterampilan Menulis. Bandung: Angkasa.

Djamarah, Syaiful Bahri. 2012. Belajar dan Pembelajaran. Jakarta: Rineka Cipta.

Khrishandiri. 2013. Pembelajaran Menulis Deskripsi dengan Menggunakan Metode Field Trip. Jurnal Bahasa, Volume 2 Nomor 2, Juli 2013. Halaman 105-119.

Komaruzzaman. 2010. Tesis. Peningkatan Kemampuan Menulis Karangan Deskripsi Siswa dengan Menggunakan Model Pembelajaran Kooperatif Tipe Roll Playing Pada Siswa Kelas V SD Negeri 2 Empat Lawang. Indralaya. Universitas Sriwijaya (tidak dipublikasikan).

Nurgiyantoro, Burhan. 2010. Pengajaran Bahasa dan Sastra Indonesia. Yogyakarta: BPFE.

Purnomo, Eka. Agus. 2010. Upaya Meningkatkan Keterampilan Menulis Deskripsi Melalui Pendekatan Kontekstual Pada Siswa Kelas IV SDN Karanggedang 03 Sidareja Cilacap Tahun Ajaran 2009/2010. Jurnal Bastra, Volume 1 Nomor 3, Oktober 2010. Halaman 52-66.

Slavin. 2014. Pembelajaran Kooperatif. Jakarta: Rineka Cipta.

Tatang. 2010. Penelitian Tindakan Kelas. Jakarta: Rajawali Pers.

Tarigan, Henry Guntur. 2012. Menulis Sebagai Suatu Keterampilan Berbahasa. Bandung: Angkasa.

Trianto. 2010. Desain Pembelajaran Kooperatif. Jakarta: Rineka Cipta. 